\title{
On the Action of a Synthetic Adrenal Cortical Steroid on the Metabolism of Epididymal Adipose Tissue of the Rat
}

\section{Yoshio IKEDA, Shoichi KOYAMA, Tomio TANESE and Masakazu ABE}

\author{
The Fourth Department of Internal Medicine, Jikei University School of Medicine, \\ Tokyo, Japan (Director : Professor Masakazu Abe, M.D.)
}

Results of in vitro and in vivo experiments on the action of adrenal cortical steroid hormone on the metabolism of adipose tissue have indicated that the hormone inhibits glucose utilization in adipose tissue.

The present paper summarizes the results of our experiments, both in vitro and in vivo, on the effect of $\beta$-methazone, a synthetic adrenal cortical steroid, on glucose uptake and insulin effect in epididymal adipose tissue of the rat.

1) $\beta$-methazone $(0.001 \gamma-10 \mathrm{r} / \mathrm{ml})$ did not effect any significant change when the medium in which the adipose tissue was immersed did not contain albumin, however, the stimulating effect of insulin $(10 \mu \mathrm{u}-1.000 \mu \mathrm{u} / \mathrm{ml})$ on glucose uptake was definitely inhibited.

2) When $2 \%$ albumin was added to the medium, $\beta$-methazone increased glucose uptake of adipose tissue, and simultaneously, increased the release of free fatty acid into the medium. These effects were not influenced by the glucose concentration of the medium or by the incubation time.

3) The insulin effect in adipose tissue was also not inhibited by the addition of $\beta$ methazone when albumin was present in the medium. However, regarding the release of free fatty acid, $\beta$-methazone acted antagonistically to insulin.

4) Basal glucose uptake and insulin sensitivity of the tissues were studied in the epididymal adipose tissue of rats which had been given $\beta$-methazone $1 \mathrm{mg}$., daily, for 3 consecutive days prior to extirpation. No significant difference in treated group and the control group, however, a decrease in insulin sensitivity was observed in the $\beta$-methazone group.

Based on the results of the aforementioned experiments, a few considerations were made on the influence of corticosteroid hormones on adipose tissue metabolism, and suggestions were made that the imbalance between lipolytic hormones such as the hypophyseal, adrenal cortical hormones and insulin may be one of the causative factors in the pathogenesis of diabetes mellitus.

(pp. 1326 1333) 


\section{脂肪組織代謝に及ぼす副腎皮質合成ステロイドの作用}

\begin{tabular}{cccc}
\multicolumn{3}{c}{ 東京慈患会医科大学阿部内科 } & \\
池 & 田 & 義 & 雄 \\
小 & 山 & 幐 & 一 \\
種 & 瀬 & 富 & 男 \\
阿 & 部 & 正 & 和
\end{tabular}

(眧和 42 年 1 月 28 日受付)

ラットの剔出副睪丸脂肪組織のブドウ糖とりてみ(glucose uptake), $\mathrm{CO}_{2}$ の発生，あるいは脂質合成など を指標として，血中に存在する微量 insulin の測定が行なわれている。一方ての組織は脂肪組織代謝を追求 するモデル組織としての有用性も高く，insulin と各種ホルモンの相互作用などが検討されて，すでに多く の知見がえられている，てのように，ラットの副金丸脂肪組織（以下副睪脂と略す）を用いる in vitroの央 験はまてとに興味深いものがあり，今後益々研究材料としての役割が高く評洒されようとしている.

成長ホルモン $(\mathrm{GH})$, glucagon など多くのホルモンは, in vitro で副等脂の glucose uptake を高めると いう点で, insulin とかなり似かよつた作用がみとめられているが，副粲皮質ホルモンは，脂肪組織の糖代 謝面で insulin の働きとは相反する作用を示すとされている。すなわち Jeanrenaud と Renold (1960) ${ }^{6}$ ，あ るいは後藤 $(1962)^{4)}$ は，副腎皮質ホルモンには in vitro で積㥛的に糖利用を抑制する効果はないとしたが， その後 Leboeuf $ら(1962)^{9}$, F F ain ら $(1963)^{3)}$, Weinges ら $(1964)^{18)}$, 葛谷ら $\left(1963^{7}, 1965^{8}\right)$ は, 副粹脂の 糖利用を副腎皮質ホルモンが明らか抑抑制するととをみとめている。さらにCorreaら $(1960)^{2)}$, 田辺 $(1961)^{14)}$, Munk ら $\left(1961^{10)}, 1962^{11}\right)$ ，は in vivo 亿副腎皮質ホルモンを投与したのちに剔出した副等脂の，insulin に 対する感受性が低下しているととを報告している。乙のような実験的事実は, 副婜皮質ホルモンが脂肪組織 代謝の場では insulin に捛抗的であることを示している.

一方ヒト，あるいは動物の糖尿病状態が，脳下垂体・副肾の剔除により著明に改善されることは周知の事 史であり，副婜皮質ホルモンが diabetogenic な㗢きをもつという点では現在全く異論がない、ただ，その 作用機序の本態という点ではなお不明といわざるを得ない。

私たちは，副篮皮質合成ステロイドである $\beta$-methazone disodium phosphate（以下 $\beta$-methazone と略 す）が，ラットの副辠脂の glucose uptake にどのような作用を及ぼすか, 又 insulin の効果に対して，ど のような作用を発揮するかを，in vitro および in vivoの実験で検討したので報告する.

\section{実 験 方 法}

1) $\beta$-methazone を in vitro で添加する実験 :

ラットの副等脂法の概略は次のでとくである.

生後 1 カ月で購入し，6 週間一定条件で飼育した体重 $180 \mathrm{~g}$ 前後の Donryu 系雄性ラットの 5 匹を一群とし て実験に供した，飽食状態のままで断頭屠殺し，直ちに開腹，副等脂を剔出， $20^{\circ} \mathrm{C} の$ Krebs-Ringer bicarbonate buffer に浸渍 (soaking) する. 30分以内の浸漬の間に各組織の遠位部分 (distal portion)より，お よそ40mgの組織 $5 \sim 6$ 片を剔出し，一括して pool する.

Incubation medium はブドウ糖を $1 \mathrm{mg} / \mathrm{ml}$ の割合に含む Krebs-Ringer-bicarbonate buffer を対照とし， 夷験群はてれに insulin，あるいは $\beta$-methazone を添加して，それぞれの glucose uptake をブドウ糖酸化 醳素法により測定し，対照と実験群とを対比した。 
Incubation は，100\%空気の気相条件で， $37.5^{\circ} \mathrm{C} ， 4$ 時間，振䔽回数 $120 /$ 分で incubator (大洋科学製) により行なつた. なお incubation medium には, dihydrostreptomycin $0.2 \mathrm{mg} / \mathrm{ml}$ を同時に添加した.

組織重量は, incubation 終了後に湿重量として測定し, glucose uptake は mg/100mg wet tissue weight/ 4hrs. incubation time として表現した.

以上のような実験方法で $\beta$-methazone と insulin とをそれぞれ単独，あるいはそれぞれをともに添加し て両者の相互作用を検討した，検討した項目は次のとおりである.

(1) Cohn のエタノール法で抽出したヒト血清アルブミンを $2 \%$ 割合に medium 内に涯加した場合と， 添加しない場合で $\beta$-methazone の効果が相違するか否か.

(2) medium 内のアルブミンの有無により示される $\beta$-methazone の効果が incubation time（2時間と 4 時䦑), ブドウ糖濃度 $(1 \mathrm{mg}$ と $3 \mathrm{mg} / \mathrm{ml}$ ) の変動によりどのように影響されるか.

なお一部の実験では，同時に遊離脂肪酸（以下 NEFA と略す）の medium 内への放出を Itaya らの变 法5゙くり測定した.

2) $\beta$-methazone を投与したラットから剔出した副睪脂を用いる実験 :

$\beta$-methazone 投与実験にも，in vitroの実験に使用したのと同一条件のラット 5 匹を一群とし，飽食状態 のまま用いた。 $\beta$-methazone $1 \mathrm{mg}(0.25 \mathrm{ml} / 100 \mathrm{~g}$ rat weight/day) を 3 日間連続皮下注射し，最終の注射後 3 時間で屠殺し，剔出した副嶧脂を用いた。乙の場合も副睪脂の glucose uptoke，ならびに添加 insulinの 効果を medium 内のアルブミンの有無などの条件によつてどのような相違が起てるかを観察した。 なお対 照群としては生理的食壏水 $(0.25 \mathrm{ml} / 100 \mathrm{~g}$ rat weight/day) を皮下注射したラットを用いた。

使用した $\beta$-methazone と結晶ブタ insulin (glucagon free) は，それぞれ塩野義製楽株式会社，および 小玉株式会社より提供されたものを用いた。

\section{笑 験 結 果}

\section{1) In vitro の実験}

(1) $\beta$-methazone, insulin 添加時の副窒脂の glucose uptake, NEFA 放出の変動一medium 内アルブミ ン存否の影響—

その結果はFig. 1 亿示す如くである. $\beta$-methazone 水溶液を, $0.001 \gamma, 0.1 \gamma お よ ひ ゙ ~ 10 \gamma / \mathrm{ml}$ の割合に添加した

Fig. 1. The effect of $\beta$-methazone and insulin on glucose uptake by rat adipose tissue in vitro
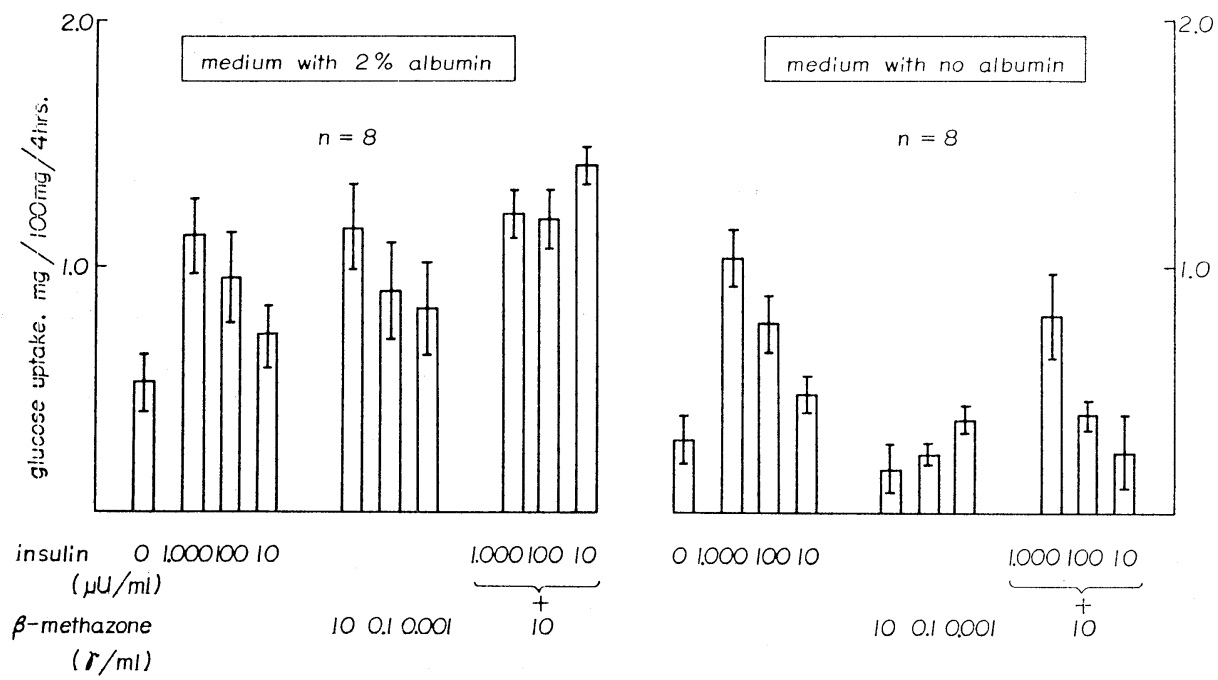
ときの glucose uptake をみると, medium にアルブミンを含まないときは基礎摄取能（ブドウ糖のみを含 む medium での副睪脂の glucose uptake) と比較して, 決して促進的な傾向はみとめられず, 高濃度では むしろ抑制されるといえよう。ささら insulin と $\beta$-methazone の相互作用をみると，10，100，1000 $\mu \mathrm{U} / \mathrm{ml}$ の insulin 単独で示される glucose uptake は, $\beta$-methazone $10 \gamma / \mathrm{ml}$ の添加こよつて明らかに抑制された.

てれに対して，mediumに正常ヒト血清アルブミンを $2 \%$ 割合に添加したときは，明らかに異なる結果 がえられた。すすなわち， $\beta$-methazone を medium に添加すると glucose uptake は增加し，しかも $\beta$-methazone は insulin の効果を抑制しないばかりか，むしろ促進的に作用する結果を得た。なお，てのさいの 副窣脂よりの NEFA の放出は，Fig. 2 亿示すように $\beta$-methazone の添加で著明に促進されたが，比較的高 濃度の insulin の同時添加沉つてての NEFA 放出の促進的効果は抑制された。 ただ $10 \mu \mathrm{U} / \mathrm{ml}$ 程度の

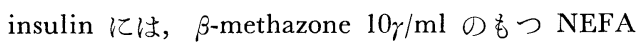
放出促進効果を抑制する作用がなく，両者の間何 かNEFA放出をめぐつて量的な拮扰関係がみられる ようであつた。

以上のように incubation medium 内のアルブミ ンの有無によつて, 副窣脂の glucose uptake に対 する $\beta$-methazone の効果に相違のあるてとが明ら かになつた。すなおち medium にアルブミンが存 在しない時は, $\beta$-methazone には積極的な glucose uptake の促進作用がみとめられない. medium に $2 \%$ 割合にアルブミンが存在すると $\beta$-methazone は glucose uptake を促進する。しかも，乙の効果 が NEFA の放出と密接な関係にあることも明らか にされた。

(2) $\beta$-methazone の効果に及ぼす incubation time と medium 内ブドウ糖濃度の影響.

結果は Table 1 亿示す如くである. medium 内の

Fig. 2. The effect of $\beta$-methazone on NEFA release from rat adipose tissue in vitro

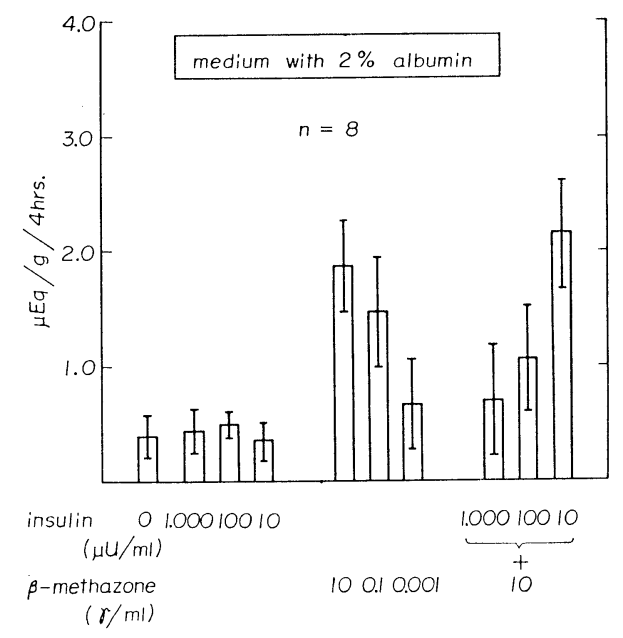

Table 1. The effect of changes of glucose concentration in medium and incubation time upon the glucose uptake by rat adipose tissue with or without albumin

\begin{tabular}{|c|c|c|c|c|c|c|c|c|}
\hline \multirow[b]{3}{*}{$\begin{array}{l}\text { Concentrations of } \\
\text { added hormone }\end{array}$} & \multicolumn{4}{|c|}{$2 \%$ albumin } & \multicolumn{4}{|c|}{ No albumin } \\
\hline & \multicolumn{2}{|c|}{2} & \multicolumn{2}{|r|}{4} & \multicolumn{2}{|r|}{2} & \multicolumn{2}{|r|}{4} \\
\hline & 1 & 3 & 1 & 3 & 1 & 3 & 1 & 3 \\
\hline Basal glucose uptake & $\left|\begin{array}{l}0.37 \\
\pm 0.04\end{array}\right|$ & $\begin{array}{l}0.64 \\
\pm 0.12\end{array}$ & $\left|\begin{array}{l}0.53 \\
\pm 0.06\end{array}\right|$ & $\mid \begin{array}{l}1.08 \\
\vdots \pm 0.09\end{array}$ & $\mid \begin{array}{l}0.42 \\
\pm 0.03\end{array}$ & $3 \mid \begin{array}{l}0.41 \\
\pm 0.08\end{array}$ & $\mid \begin{array}{l}0.33 \\
\pm 0.02\end{array}$ & $2 \mid \begin{array}{l}0.76 \\
\pm 0.05\end{array}$ \\
\hline Insulin $100 \mu \mathrm{U} / \mathrm{ml}$ & $\left|\begin{array}{l}0.56 \\
\pm 0.03\end{array}\right|$ & $\begin{array}{l}1.12 \\
\pm 0.11\end{array}$ & $\begin{array}{l}0.95 \\
\pm 0.11\end{array}$ & $1 \quad \begin{array}{l}1.73 \\
\pm 0.12\end{array}$ & $\begin{array}{l}0.83 \\
\pm 0.05\end{array}$ & 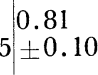 & $\begin{array}{c}0.93 \\
0 \pm 0.09\end{array}$ & $9 \begin{array}{l}1.32 \\
\pm 0.17\end{array}$ \\
\hline$\beta$-methazone $10 \gamma / \mathrm{ml}$ & $\left|\begin{array}{l}0.66 \\
\pm 0.04\end{array}\right|$ & $\begin{array}{l}1.28 \\
\pm 0.14\end{array}$ & $\begin{array}{l}1.17 \\
\pm 0.12\end{array}$ & $2 \mid \begin{array}{l}1.68 \\
\pm 0.13\end{array}$ & $\begin{array}{l}0.14 \\
\pm 0.03\end{array}$ & $\begin{array}{l}0.36 \\
3 \pm 0.05\end{array}$ & $5 \begin{array}{l}0.17 \\
\pm 0.07\end{array}$ & $7 \mid \begin{array}{l}0.59 \\
\pm 0.06\end{array}$ \\
\hline Insulin $100 \mu \mathrm{U} / \mathrm{ml}+\beta$-methazone $10_{\gamma} / \mathrm{ml}$ & $\mid \begin{array}{l}0.72 \\
\pm 0.05\end{array}$ & $\begin{array}{l}1.10 \\
\pm 0.09\end{array}$ & $\begin{array}{l}1.20 \\
\pm 0.07\end{array}$ & $7 \mid \begin{array}{l}1.76 \\
\pm 0.10\end{array}$ & 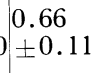 & 10.56 & $\begin{array}{l}0.39 \\
9 \pm 0.02\end{array}$ & $2 \pm 0.11$ \\
\hline
\end{tabular}

glucose uptake $:$ mean \pm S.D. $(\mathrm{mg} / 100 \mathrm{mg} /$ incubation times)

No. of Exp. $=8$ 
アルブミンの有無によつて, 副辠脂の glucose uptake に及ぼす $\beta$-methazone の効果は明らかに相違すること が明らかになつたが，ての相違はただ単に medium 内のアルブミンの有無にのみ関与するものであろうか？ 他の実験条件によつても影響される可能性が充分に考えられたので，次に， medium 内のブドウ糖濃度を変 えたり, incubation time を変化させた場合にどのような影響が出現するかを検討してみるてとにした。 て の場合の実験は $\beta$-methazone の添加量を $10 \gamma / \mathrm{ml}$, insulin の添加量を $100 \mu \mathrm{U} / \mathrm{ml}$ と一定にして行なつた. medium にアルブミンが存在しないとと, incubation time を 2 時間と 4 時間, ブドウ糖浱度を $1 \mathrm{mg}$, $3 \mathrm{mg} / \mathrm{ml}$ と変化させても, 副䅅脂の glucose uptake, および添加 insulinの効果に対して, $\beta$-methazone は決して促進的な作用を示すことなく，むしろ明らかに抑制的であつた。

これに対して， medium にアルブミンを $2 \%$ 割合に存在させると， incubation time，およびブドウ糖 濃度の変化には無関係に， $\beta$-methazone は副殬脂の glucose uptake を促進し，又 insulin効果をも妨げな いととが分かつた。

2) in vivo の実験 $\beta$-methazone 投与ラットから剔出した副錊脂の glucose uptake および insulin に対 する感受性

Fig. 3. The basal glucose uptake and insulin sensitivity of rat adipose tissue isolated from $\beta$-methazone treated rats

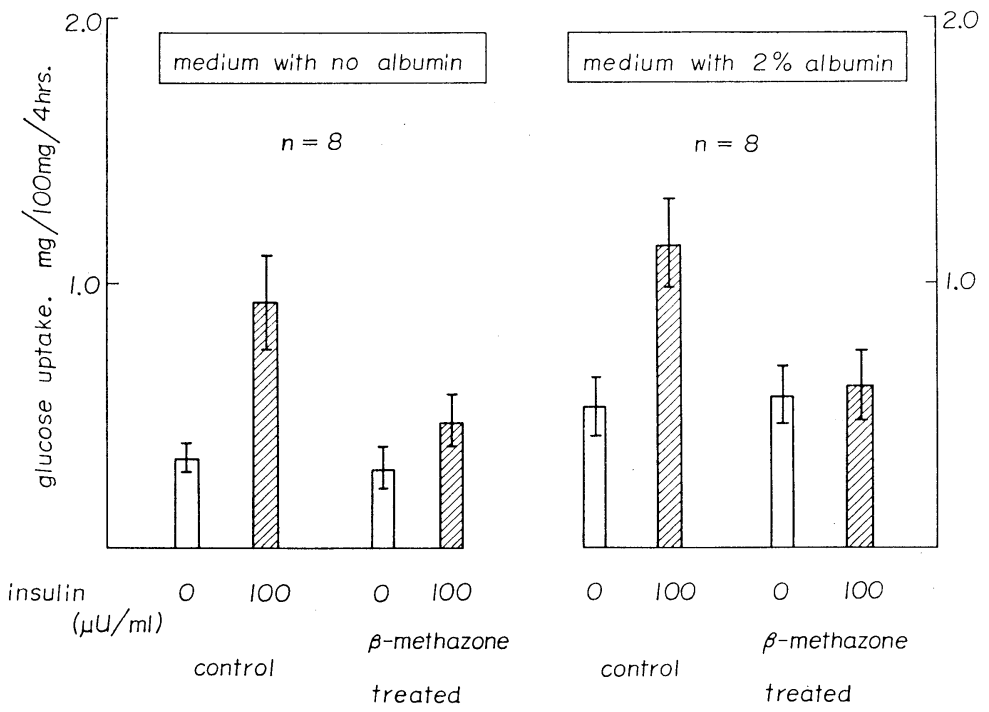

結果はFig. 3 に示す如くである. ラットに $\beta$-methazone を 3 日間連続皮下注射を行なつた後, 剔出した 副梓脂を用い, glucose uptake, および insulin $100 \mu \mathrm{U} / \mathrm{ml}$ に対する感受性を対照と比較すると同時に，乙 れが medium 内のアルブミンの存否により，いかに影響されるかを検討し次の結果を得た。

$\beta$-methazone を in vitro に添加した場合の成績とは異なり，いずれの場合も， $\beta$-methazone 投与ラット から得た副奧脂の insulin 飞対する感受性は, 対照に比較して, 明らかな低下をみとめた。しかしbasalの glucose uptake には，両群の間に有意の差はみとめられなかつた。

\section{実験結果に対する考察}

in vitro に添加した副腎皮質ホルモンが脂肪組織代謝にいかなる影響を及ぼすかについては，Jeanrenaud と Renold $(1960)^{6)}$ の報告がある. 彼らは medium にアルブミンが存在すると，副腎皮質ホルモン添加に より NEFA 放出の増大がみとめられるが，ブドウ糖利用の面には，なんら積極的な作用を及ぼさないと報 
告した。しかし，その後の研究で，Leboeuf ら $(1962)^{9}{ }^{9}$ は cortisol $30 \gamma / \mathrm{ml}$ の添加が NEFA の放出を盛ん

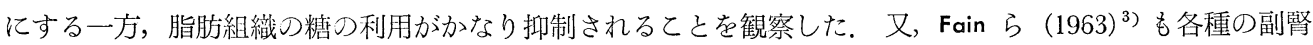
皮質合成ステロイドを使つた in vitro の実験でほぼ同様な結果を得たが，それとともに，添加した insulin

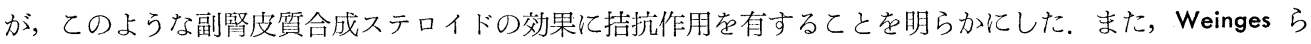
${ }^{\left.(1964)^{18}\right)}$ は，同じく cortisol 30r/ml が NEFA の放出を対照化比し3.5倍も增大させるのに対して，糖の利 用面では逆に50\%の抑制がみられるととと，又insulin $100 \mu \mathrm{U} / \mathrm{ml}$ の効果も cortisol によつてほぼ半減される ことをみとめた，彼はての事実をもとにして副婜皮質ホルモンの催糖尿病作用は，肝における糖新生の增大 とは無関係に，末梢組織，とくに脂肪組織での糖利用抑制効果に求めるべきてとを主張している.

本邦では矮松(1961) ${ }^{17}$ が medium にアルブミンが存在しないという条件下で, 副睪脂の glucose uptake に及ぼす insulin の効果が, cortisone の 2.5 25r/ml の添加で干渉されるととを，また葛谷と森 $(1963)^{8)}$ は, cortisone $60 \gamma / \mathrm{ml}$ を添加したさいの副涬脂の糖利用が， medium 内のブドウ糖濃度の低い埸合 $(1 \mathrm{mg} /$

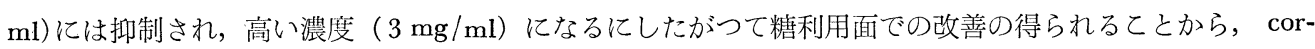
tisone の作用に対する medium 内のブドウ糖濃度の影響という点に注目している.

また，副腎皮質ホルモンの副鋅脂での作用が，incubation time によつてどのように影響されるかについ $\tau$, Fain ら $(1963)^{3)}$ とWeinges ら $(1964)^{18)}$ は，少なくとも2 時間以内つ incubation では，対照との間 に差異がみとめられず，4 時間以上の incubation によつてはじめて副緊皮質ホルモンの作用が出現すると 述べてる。

私たちの実験成績からは，副腎皮質合成ステロイドの一つである $\beta$-methazone は，in vitro での実験条 件の相違によつて，副辠脂のブドウ糖利用面に異なる結果のえられるととが明らかになつた。すなおち medium そアルブミンが $2 \%$ 割合に存在すると, medium 内のブドウ糖濃度, あるいは incubation time とは無関係に， $\beta$-methazone が副睪脂への glucose uptake をさかんにするとと，同時に medium への NEFAの放出が増大するてとが分かつたのである。乙の事実は従来の諸家の成績とは全く異なるものといえ る。もちろん medium 内へ添加したアルブミン自身にも，副峷脂での glucose uptake を促進する作用が あるが， $\beta$-methazone の添加により，glucose uptakeはさらに増大するてとがみとめられた。 しかし, medium にアルブミンが存在しないと，矮松 ${ }^{17} か ゙ ，$ cortisone で確認したのと同様に $\beta$-methazone が副宰脂の glucose uptake を抑制し，同時に添加した insulin 効果をも抑制したのである.

medium 内にアルブミンが存在していれば, 副等脂外への NEFA の放出は可能であるが, このような条 件下では，一般に脂肪異化ホルモン(lipolytic hormone, たとえば GH, glucagon, ACTHなど) は, 副辠 脂による glucose uptake を促進することが知られている．副婜皮質ホルモンを除いた，他の脂肪異化ホル モンは, 脂肪組織における glucose uptake の增大, ブドウ糖から glycerol への系路の促進, および $\mathrm{CO}_{2}$ への 系路の促進などをもたらすが，乙の変化の要因は，結局，脂肪組織での NEFA 産生および放出の增加が第 一義的なものとされている．いつたい，なぜ NEFA の増大が，脂肪組織での糖代謝の変動をひきおてすか については不明な点が多いが，現在ではおよそ次のように考光られているといつてよからう。すなわち，脂 肪組織での NEFA と glycerol からの脂肪合成は肝臟の場合と同じように, NEFA はまず GoA 誘導体に なり, glycerol は $\alpha$-glycerophosphate になつてからエステル化される.したがつて, いま脂肪の分解が䒕 進して NEFA の増量がおこると $\alpha$-glycerophosphate の相対的な不足がおてり, 脂肪合成が円滑に進展し なくなる，そてで解糖を盛んにしててれを補い，一方で酸化を盛んにしてェネルギーを得て NEFA は CoA 誘導体になるのであろうと考朰れている.

一方, medium 内にアルブミンが存在しないと, 副蛙脂からの NEFA の放出が，carrier の久如のため 停止してしまう。乙の場合脂肪異化ホルモンが脂肪組織の糖代謝にいかなる影響を及ぼすかについては,

Verner ら (1962) ${ }^{16)}$ の興味深い報告がある。すなわち，彼らは，ACTH， adrenaline および noradrenaline が副闰脂の glucose uptake を抑制し，同時に添加された insulin の効果も阻止するてとを認めた。 そして このような場合，副䔂脂の glucose uptake と組織内に増量する NEFA 量の間に負の相関を認めた。 ての 
ようにして脂肪異化の充進がおきている状態での glucose uptake は medium 内にアルブミンが高濃度に存 在すると促進されるが，アルブミンが存在しないと，かえつて抑制されるてとを示したのである。私たちが $\beta$-rnethazone で観察した成績とほぼ同様である。乙のような現象がみられる理由については，NEFA が無 制限に組織内に蓄積すると，脂酸自身によるか，あるいはその代謝産物による toxic effect が現われ，乙の 効果が glucose uptake を抑制するのではないかという可能性を推定している.

汸, glucagon と GHについては, medium にアルブミンが存在しなくても, 副殬脂のglucose uptake

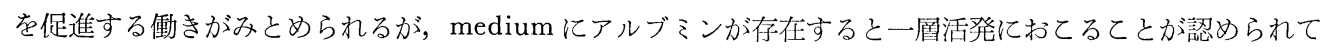
いる. これは脂肪異化ホルモンに共通な現象として興味深い.

以上のような in vitro の実験では, 実験条件の相違によつて, 特定物質の作用が，かなり違つて出現す るととはよく知られているとてろである。乙てで各報告者の実験条件の相違をくわしく検討する余裕はない が，とくに注意を要する点は, medium 内のブドウ糖莀度と, incubation time の相違である。 そてで medium 内のアルブミンの有無によつて得られた $\beta$-methazone の全く相反する効果が，乙れらの実験条件で 影響されるものか否かについて検討したが，そのような事実は認められなかつた。

一方, in vivo の面からも, 副腎皮質ホルモンの脂肪組織代謝におよぼす影響が検討されている. Correa ら $(1960)^{2)}$ は，3.5日間にわたつて $7 \mathrm{mg}$ の cortisone を投与したラットから剔出した副殬脂の, 微量インス リン $(20 \sim 50 \mu \mathrm{U} / \mathrm{ml})$ に対する感受性が。抑制されているととをみとめている。 また， Munk ら (1951) ${ }^{10)}$ $(1962)^{11)}$ は， cortisol $2.5 \mathrm{mg}$ を投与後 1 時間半以内に剔出したラット副䔂脂の glucose uptake が，刘照と 比較して抑制されたとしている. 本邦では, 田辺 $(1961)^{14)}$ が prednisolone 投与ラットを用いてほぼ同様の 結果を得ている。，一方，葛谷 $(1963)^{7)}$ は，副腎剔出ラットを用いて，屠殺 2 時間前に $2.5 \mathrm{mg}$ の cortisone を 投与すると血糖上昇の認められるとと，またてのラットから剔出した副丵脂の $\mathrm{G}^{14}$-glucose から $\mathrm{C}^{14} \mathrm{O}_{2} の$ 発生，および脂質へのとりてみが，刘照に比較して低下することを認めている．てれらの成績は，今回私た ちが $\beta$-methazone を投与したラットの副梓脂について得た実験成績とほぼ同様である，なお，ての場合medium 内のアルブミンの存否によつて, 脂肪組織のインスリン感受性になんらの変化がみられなかつたてと はまととに興味深いととである。

副腎皮質ホルモンを生体に投与して, 糖尿病状態が招来されるてとはすでによく知られた事実である。膵 剔を行なうと，48時間以内に重篤な代謝性アシドーシスに宿つて死亡するが，予じめ副㛑を剔除しておくと， lipid mobilization がおてらないでケトーシスが発生しないとされている ${ }^{13)}{ }^{15}$. 又, Ashmore (1964) ${ }^{1)}$ によ れば，抗インスリン血清を正常ラットに投与すると，急速な血糖上昇，血中 NEFA の増大がおてるが，予 じぬ下垂体剔除を行なうと，乙れらの現象がみられないのに，cortisol の投与を行なつておくと再び，高血 糖, 高脂血症か認められると報告している。

さててういつた副腎皮質ホルモンを中心とした下垂体副腎系の diabetogenic action はいかなる要因によ るものであろうか?.また，予め in vivo 亿副婜皮質ホルモンを投与した後に剔出した脂肪組織の insulin 感受性の低下，あるいは in vitro の実験でみられた medium 内アルブミンの有無により，副袩皮質ホルモ ンの glucose uptake に相反する効果がみられるという各種の事実がもつ意義は，副腎皮質ホルモンのdiabetogenic action とどのような関連性があるのだろうか?

以上の問題は副婜皮質ホルモンの脂肪組織に対する働きを，次のように考えると解決への道が示唆される ように思う。すなわち，副婜皮質ホルモンの脂肪組織代謝に及ぼす影響の第一義的なものは，なんといつて もその脂肪異化作用にあるというととと, 糖利用面に現われる効果はその二次的な影響によるものだという ことである．つまり，副腎皮質ホルモンには脂肪組織での糖利用を直接に抑制する作用はなく，乙の作用は あくまで脂質代謝の変動に起因した二次的な現象として解釈しょうというわけである.

以上の観点から，私たちがラットの副睾脂を用いて示した実験成績をもう一度みなおしてみよう。Medium 内にアルブミンが存在しない時の $\beta$-methazone の糖利用抑制, 抗 insulin的な効果は, $\beta$-methazone のもつ脂肪異化作用によつて, 組織内に NEFA が蓄積し, この結果, 糖利用面が抑制されるもので, $\beta$-me- 
thazone そのものの直接作用ではないと考光られる. 又, medium 内にアルブミンが存在すると medium 中の NEFA の增量が trigger となつて糖利用面が促進されるのではなからうか. 一方, in vivo に $\beta$-methazone を投与した後に剔出した副䔂脂の insulin 感受性の低下は, medium 内のアルブミンの存否に無関 係に認められるが，てれは $\beta$-methazone の投与により，生体内で lipid mobilization の充進がおてり，脂 質合成面に強い働きをる insulin 作用が発揮されにくくなつたのではないかと考光る。しかし，乙の場合， 投与した $\beta$-methazone の metabolite が insulin 阻害作用を示すととの可能性も否定できない. 今後さら に充分な検討が必要なものと考光る。

最近 Randle 弓 (1964) $\left.{ }^{12}\right)$ は，糖尿病患者の血中 NEFA 值の増大に注目し，てのような NEFA の增量す るような生体内のメカニズムが，糖尿病の病团に大きな役割を演じる可能性を glucose fatty acid cycle と いう概念で説明している。 てのような脂肪組織代謝の歪みは, ただ単に insulin 欠乏という一つの現象によ るものではなく，おそらく下垂体副腎皮質系との関連の上に insulin と抗 insulin 系ホルモン，いわゆる脂 肪異化ホルモンとの不均衡が原因しておてるものと考光られる。いずれにしても，てのような異常が，糖尿 病の病因につながる可能性が考えられ，まてとに興味深い.

総 括

副腎皮質ホルモンの脂肪組織糖代謝に及ぼす作用については，in vitro でも，in vivo でも脂肪組織の糖 利用を抑制する作用が報告されている，私たちは，副腎皮質合成ステロイドである $\beta$-methazoneが，ラッ 卜の副睪丸脂肪組織（副睪脂）の glucose uptakeにどのような作用を及ぼすか，又，insulinの効果にどの ような作用を発揮するかを，in vitro および in vivo の実験で検討したとてろ，てれまでの知見と一部異 なる結果が得られた。

(1) 副罯脂の medium そアルブミンが含まれていない場合の glucose uptake は, $\beta$-methazone の有無 によつて有意の変化はみられないが, insulin $10 \sim 1.000 \mu \mathrm{U} / \mathrm{ml}$ の示す glucose uptake の促進は, $\beta$-methazone の添加により明らかに抑制された。

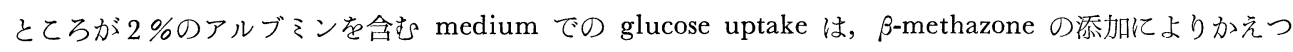
て増大し，同時に medium 内への NEFA の盛んな放出がみられた，又，glucose uptake に及ぼす insulin 効果は，アルブミンの存在しない条件の場合とは異なり $\beta$-methazone によつて決して抑制されなかつたが, NEFA の放出については, insulin と拮抗的であつた。 なお，アルブミンを含む medium で示された $\beta$-methazone の glucose uptake 促進作用は, medium 内のブドウ糖濃度, あるいは incubation の時間の変動 によつては,なんら影響をうけなかつた。

（2）予め，in vivo に $\beta$-methazone を投与したのちに剔出したラットの副䆭脂について，ブドウ糖基礎 摄取能および insulin 亿対する組織の感受性を, 対照と比較したとてろ, ブドウ糖基礎摄取能には, 両群の 間に有意差を認めなかつたが，insulin に対する感受性では，実験群に明らかな低下を認めた。

以上の実験成績を基にして副腎皮質ホルモンの脂肪組織代謝に及ぼす働きについて考察し, 糖尿病の発症 が insulin と副腎皮質ホルモンを中心とする脂肪異化ホルモンとの imbalance によつてもたらされる可能 性について述べた。

この諭文の要旨は第38回日本内分泌学会総会で発表した。 $\beta$-methazone を提供された塩野義製薬株式会社, glucagon free insulin を提供された小玉株式会社に深甚の謝意を表する.

\section{文献}

1) ASHMORE, J. : The effects of glucocorticoids on insulin action, Diabetes, $13: 349$, (1964).

CORREA, P.R., E. MAGALHAES, and M.E. KRAHL : Response of epididymal adipose tissue to small concentrations of insulin, Proc. Soc. exp. Biol. and Med., 103 : 704, (1960).

3) FAIN, J. N., R.O. SGOW and S.S. CHERNICK : Effects of glucocorticoids on metabolism of adipose tissue in 
vitro, J. biol. Chem., $238:$ 54, (1963).

4) 後藤由夫 : 副腎と糖代謝, 日内分泌誌, $38: 571,(1962)$. 5) ITAYA, K. and M. UI : Colorimetric determination of free fatty acids in biological fluids, J. Lipid. Research, $6: 16$, (1965). $\quad$ 6) JEANRENAUD, B. and A.E. RENOLD : Studies on rat adipose tissue in vitro : Effects of adrenal cortical hormones, J. biol. Chem., $235: 2217$, (1960).

7) 葛谷覚元 : Cortisone glucose tolerance test (CGTT) の検討, 糖尿病, $6 ; 35$, (1963). 8) 葛谷 覚元，森克己：脂肪組織代謝に及ぼすホルモンの影響, 日内分泌誌, $40 ； 1272,(1965)$. 9) LEBOEUF, B., A.E. RENOLD and G.F. CAHILL : Studies on rat adipose tissue in vitro: IX. Further effects of cortisol on glucose metabolism, J. biol. Ghem. $237: 988$, (1962). 10$)$ MUNK, A. : The effect of cortisol on glucose uptake by rat epididymal fat pads, Endocrinology, $68: 178,(1961)$. 11) MUNK, A. and S. KOLITZ : Studies on the mode of action of glucocorticoids in rats, Biochim. Biophys. Acta., $57:$ 310, (1962). 13) RANDLE, P.J., P.B. GARLAND G.N. HALES and E.A. NEWSHOLME : The glucose fatty acid cycle and diabetes mellitus, Giba Foundation Colloquia on Endocrinology, $15: 193$, (1964). 13$)$ SCOW, R.O., S.S. GHERNICK and B.N. GUARZO : Ketogenic action of pituitary and adrenal hormones in pancreatectomized rats, Diabetes, $8: 132,(1959)$. 14）田辺精一：白鼠副睪丸脂肪組織の糖質並びそ脂質代謝に関する研究，日内分泌誌，37；751，(1961）.

15) URGOITI, E.J., B.A. HOUSSAY and G.T. RIETTI : Hypophyseal and adrenal factors essential for ketoacidosis of pancreatectomized dogs, Diabetes, $12: 301$, (1963). 16) VERNER, J.V., W.G. BLAGKARD and F.L. ENGEL : Some factors modifying the actions of hormones on glucose uptake by adipose tissue in vitro, Endocrinology, $70: 420,(1962)$ 17) 矮松一弥: 脂肪組織に おける糖代謝の研究, 日内分泌誌, 37 ; 723, (1961). 18) WEINGES, K.F. and G. LÖFFLER : Der Einfluss von Cortisol auf den Insulineffekt am Fettgewebe in vitro, Klin. Wochenschrift, 42 : 502, (1964). 